\title{
SURGICALLY INDUCED ASTIGMATISM AFTER UPPER EYELID SURGERY IN ADULT PATIENTS
}

\author{
YETIŞKIN HASTALARDAKI ÜST KAPAK CERRAHISI SONRASI CERRAHIYE BAĞLI \\ ASTIGMATIZMA
}

\author{
Emre ALTINKURT ${ }^{1}$ iD, Nihan AKSU CEYLAN ${ }^{1}$ (i) \\ ${ }^{1}$ Istanbul University, Istanbul Faculty of Medicine, Department of Ophthalmology, Istanbul, Turkey
}

ORCID IDs of the authors: E.A. 0000-0001-7967-825X, N.A.C. 0000-0003-3724-7659

Cite this article as: Altinkurt E, Aksu Ceylan N. Surgically induced astigmatism after upper eyelid surgery in adult patients. J Ist Faculty Med 2020;83(3):193-6. doi: 10.26650/IUITFD.2019.0101

\section{ABSTRACT}

Objective: Surgical repositioning of the eyelids may change astigmatism. The change in astigmatism may affect the results of previous refractive procedures.

Material and Method: Twenty-eight eyes of 18 patients were included in the study. Interpalpebral fissure height (IPF), margin reflex distance 1 and 2 (MRD 1-2), and levator function (LF) were recorded in all patients preoperatively and at the postoperative third month. Keratometric values were measured by Scheimpflug corneal topography. Surgically induced astigmatism values due to upper eyelid surgery were calculated using a vectorial analysis program.

Results: The mean age of the patients was $45.46 \pm 18.8$ years. Blepharoplasty was performed in 11 eyes with dermatochalasis. Levator resection was performed in nine of 11 eyes with ptosis, and frontalis suspension was performed in the remaining two eyes with ptosis. Blepharoplasty with levator resection was performed in six eyes where ptosis coexists with dermatochalasis. There was no significant difference between preoperative and postoperative keratometric and LF values. However, there was a significant increase in IPF and MRD 1 values. Mean surgically induced astigmatism was $0.54 \pm 0.22 \mathrm{D}$.

Conclusion: Upper eyelid surgery can induce astigmatism. Therefore, it might be better to perform upper eyelid surgery before refractive procedures.

Keywords: Astigmatism, eyelids, surgery

\section{ÖZET}

Amaç: Göz kapaklarının cerrahi olarak yeniden konumlandırılması astigmatizmayı değiştirebilir. Astigmatizmadaki değişim önceki refraktif prosedürlerinin sonuçlarını etkileyebilir.

Gereç ve Yöntem: Çalışmaya 18 hastanın 28 gözü dahil edildi. Preoperatif ve postoperatif üçüncü ayda interpalpebral fissür yüksekliği (IPF), marjin refleks mesafesi 1 ve 2 (MRD 1-2) ve levator fonksiyonu (LF) kaydedildi. Keratometrik değerler Scheimpflug kornea topografisi ile ölçüldü. Üst göz kapağı ameliyatı nedeniyle cerrahi olarak indüklenen astigmatizma değerleri vektöryel analiz programı kullanılarak hesaplandı.

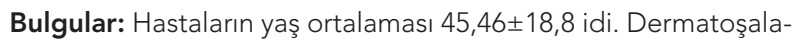
zisli 11 göze blefaroplasti yapıldı. Pitozu olan 11 gözün dokuzuna levator rezeksiyonu, ikisine frontal asma uygulandı. Pitoz ve dermatoşalazisli altı göze levator rezeksiyonu ile birlikte blefaroplasti yapıldı. Preoperatif ve postoperatif keratometri ve LF değerleri arasında anlamlı fark yoktu. Ancak, IPF ve MRD 1 değerlerinde anlamlı bir artış vardı. Cerrahi olarak indüklenen astigmatizma

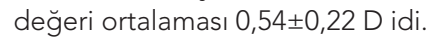

Sonuç: Üst göz kapağı ameliyatı astigmatizmayı indükleyebilir. Bu nedenle, üst göz kapağı ameliyatının refraktif işlemlerden önce yapılması daha iyi olabilir.

Anahtar Kelimeler: Astigmatizm, cerrahi, göz kapakları

Corresponding author/iletişim kurulacak yazar: altinkurtemre@gmail.com

Submitted/Başvuru: 16.12.2019• Revision Requested/Revizyon Talebi: 27.12.2020 •

Last Revision Received/Son Revizyon: 11.03.2020 • Accepted/Kabul: 20.04.2020 • Published Online/Online Yayın: 24.06.2020

(C)Telif Hakkı $2020 \mathrm{~J}$ Ist Faculty Med - Makale metnine jmed.istanbul.edu.tr web sayfasından ulaşılabilir.

(C) Copyright 2020 by J Ist Faculty Med - Available online at jmed.istanbul.edu.tr 


\section{INTRODUCTION}

Surgical repositioning of the eyelids increases the pressure vectors on the cornea, and this may change astigmatism in with-the-rule direction $(1,2)$. It has been reported that the upper eyelid gold weight implantation resulting in 1.4 \pm 2.0 diopters increases in corneal astigmatism in the vertical axis caused by compression of the upper eyelid (3). Knowing that a change in astigmatism will occur after eyelid surgery in patients with ptosis and dermatochalasis is important. If a patient with upper eyelid pathology undergoes refractive surgery, the change in astigmatism after eyelid surgery may affect results of the refractive surgery. Since surgically induced astigmatism may be significant, surgeons may wish to postpone any refractive surgery until after upper eyelid surgery is performed. For these reasons, surgically induced astigmatism after upper eyelid surgery in adult patients was examined in this study.

\section{METHODS}

After approval from the Institutional Ethics Committee of the Istanbul Faculty of Medicine, informed consents were obtained from patients to participate in the study in accordance with the Declaration of Helsinki. The records of 53 patients older than 18 who were treated for ptosis and/or dermatochalasis between January 2013 and July 2016 were retrospectively reviewed. Among 18 patients, 28 eyes were examined by corneal topography pre- and postoperatively. If measurement quality was appropriate and the follow-up period was at least three months, they were included in the study. Patients with dry eye, irregular astigmatism and keratoconus were excluded from the study. Best corrected visual acuity, intraocular pressure, and dilated fundus examinations were performed preoperatively and on the third month postoperatively. The presence of dermatochalasis, the amount of ptosis, interpalpebral fissure height (IPF), LF, and margin reflex distance (MRD) 1 and 2 were recorded in all patients. IPF was determined by measuring the distance between the upper and lower lids with a ruler from the pupil level, and LF was assessed by applying pressure on the eyebrow with a finger and making the patient look up and down. The distance between the light reflex obtained from the pupil center and edge of the upper lid was considered to be MRD-1, and the distance between the light reflex obtained from the pupil center and edge of the lower lid was considered to be MRD-2. Preoperative corneal topography of the patients was obtained by an experienced technician under scotopic conditions with a Pentacam $\mathbb{R}$ HR (OCULUS Inc., Wetzlar, Germany) without pupillary dilatation, and measurements were repeated at the third postoperative month. The keratometry values obtained from corneal topography were calculated and obtained by Eğrilmez and Dalkılıç's vectorial analysis program pre- pared for astigmatism analysis, and surgically induced astigmatism values due to eyelid surgery $(4,5)$.

The surgical treatment was chosen according to LFs and the presence of dermatochalasis. Frontalis suspension was performed in eyes with a LF less than $5 \mathrm{~mm}$, and levator resection was performed in eyes with a LF more than $5 \mathrm{~mm}$. An upper eyelid blepharoplasty was performed in the presence of dermatochalasis. When ptosis was found with dermatochalasis, levator resection was added to surgery. Frontalis suspension surgery was performed using the Fox pentagon technique while using a frontalis suspension set with a silicone tube (Beaver-Visitec International, Inc., Waltham, MA, USA) (6).

Levator resection was performed by making a horizontal cutaneous and subcutaneous incision at the upper eyelid fold or 8-10 $\mathrm{mm}$ from edge of the eyelid, opening the orbital septum and reaching the levator aponeurosis under the preaponeurotic fat tissue. The Levator resection was performed according to the degree of ptosis. The lid position was then evaluated and sutured by passing through the double-needle 6.0 Vicryl suture from the tars and levator aponeurosis.

After determining the amount of skin to be excised using the "pinch" technique, upper eyelid blepharoplasty was performed by removing the skin and preseptal orbicularis muscle after incision from the upper eyelid fold or 8-10 $\mathrm{mm}$ from the lid edge, opening the orbital septum and excising the fat packets (7). In patients who had levator surgery added to blepharoplasty, the levator resection was also performed as described above.

The Mann-Whitney-U test and IBM SPSS Statistics for Windows (Version 21.0. Armonk, NY:IBM Corp.) were used for statistical analysis of the data. $\mathrm{P}<0.05$ was considered significant.

\section{RESULTS}

Included in the study were results comprised of 28 eyes from 18 patients with a mean age of $45.46 \pm 18.8$. Ten of the patients (55.6\%) were male, and eight (44.4\%) were female.

Blepharoplasty was performed in 11 eyes with dermatochalasis. Levator resection was performed in nine of 11 eyes with ptosis, and frontalis suspension was performed in the remaining two eyes. Blepharoplasty with levator repair was performed in six eyes with ptosis and dermatochalasis.

There was no significant difference between preoperative and postoperative keratometric (K1 and K2) values and LF values (Table 1). However, there was a significant increase in IPF and MRD 1 values (Table 1).

Mean surgically induced astigmatism was $0.54 \pm 0.22 \mathrm{D}$. 
Table 1: Comparison of preoperative and postoperative measurements

\begin{tabular}{lccc}
\hline & Preoperative & Postoperative & P value* $^{*}$ \\
K1 (Diopter) & $42.76 \pm 1.11$ & $42.81 \pm 1.21$ & 0.385 \\
K2 (Diopter) & $44.21 \pm 1.08$ & $44.71 \pm 1.23$ & 0.256 \\
Interpalpebral fissure height $(\mathrm{mm})$ & $6.67 \pm 1.83$ & $9.2 \pm 1.61$ & 0.006 \\
Levator function $(\mathrm{mm})$ & $12.56 \pm 4.04$ & $13.55 \pm 2.48$ & 0.132 \\
Margin reflex distance 1 $(\mathrm{mm})$ & $2.1 \pm 0.23$ & $4.1 \pm 0.32$ & 0.008 \\
\hline
\end{tabular}

K1: Flat keratometry, K2: Steep keratometry, *Mann-Whitney-U test

\section{DISCUSSION}

Visual near and distance acuity is significantly impaired by residual astigmatism after cataract surgery (8). Even a spherical equivalent refraction of $\pm 0.5 \mathrm{D}$ can cause spectacle dependence in patients (9). Distance-spectacle dependence after bilateral monofocal intraocular lens implantation is determined by the amount of astigmatism (9). After multifocal intraocular lens implantation, distance and near vision of the eyes are impaired with residual astigmatism greater than 1.0 diopter (10). There are conflicting results in existing literature regarding astigmatism change after upper eyelid surgery. Simsek et al. reported that $60 \%$ of eyes showed a significant increase in corneal astigmatism $(-0.15 \pm 0.68)$ and Altin Ekin and Karadeniz Ugurlu reported $0.22 \mathrm{D}$ of decrease in astigmatism after upper eyelid blepharoplasty (11). However, Dogan et al. did not report any significant change after upper eyelid blepharoplasty $(12,13)$. Savino et al. reported a reduction in corneal astigmatism of $0.26 \pm 1.12 \mathrm{D}$ after the anterior levator complex tightening for ptosis surgery. On the other hand, Gingold et al. reported no statistical change after ptosis surgery $(14,15)$. Kim et al. reported that corneal astigmatism decreased in $50 \%$ of the eyes (average $0.60 \mathrm{D}$; range $0.25-1.00 \mathrm{D}$ ) and increased in $19.2 \%$ of the eyes (average $0.40 \mathrm{D}$; range $0.25-0.50 \mathrm{D}$ ). They showed no change in $30.8 \%$ of the eyes in patients who underwent levator resection, while astigmatism decreased in 16.7\% of the eyes (average 0.25 D; range 0.25-0.25 D), increased in $16.7 \%$ of the eyes (average $0.25 \mathrm{D}$; range $0.25-0.25 \mathrm{D}$ ) and showed no change in $66.7 \%$ of the eyes in patients who underwent blepharoplasty (16). Holck et al. reported $72 \%$ of eyes steepened along the $90^{\circ}$ axis and $14 \%$ of eyes steepened along the $180^{\circ}$ axis six weeks after ptosis surgery, but regression toward the amount and pattern of preoperative astigmatism in all of the operated eyes was seen one year after surgery (17). Kao et al. found an insignificant decrease of $0.18 \mathrm{D}$ in astigmatism following congenital ptosis surgery (18). However, Klimek et al. observed a postoperative 1.23 $\mathrm{D}$ decrease in sphere $(p=0.061)$ and a $0.83 \mathrm{D}$ increase in cylinder $(p=0.002)$ after unilateral levator resection in patients with congenital ptosis (19).
Changes in astigmatism after blepharoplasty and ptosis surgeries have been compared in previous studies. Zinkernagel et al. reported a $0.25 \mathrm{D}$ astigmatism change after ptosis and a $0.21 \mathrm{D}$ astigmatism change after blepharoplasty surgery (20). Brown et al. reported greater values than Zinkernagel et al., but postoperative astigmatism changes were similar between the groups $(0.57 \mathrm{D}$ for the blepharoplasty group and $0.60 \mathrm{D}$ for the ptosis group) (21). On the other hand, Kim et al. reported that levator resection surgery showed significantly greater changes in corneal curvature than blepharoplasty (22). The differences in the results of previous studies may be due to differences in the sample sets or due to differences in follow-up times.

In our study, surgically induced astigmatism after superior eyelid surgery was calculated to be $0.54 \pm 0.22 \mathrm{D}$. If a patient having upper eyelid pathology undergoes a refractive surgery such as toric intraocular lens implantation, presbyopia-correcting intraocular lens implantation or laser refractive surgery, the change in astigmatism after eyelid surgery may affect results of the previous refractive surgeries. Patient satisfaction after refractive surgery might be impaired if surgically induced astigmatism after superior eyelid surgery is not considered.

To our knowledge, this is the first study that used a surgically induced astigmatism program to calculate the change of astigmatism after upper eyelid surgery. The sample size in our study was relatively small. It would be better to confirm the results in further studies with larger patient groups.

In conclusion, upper eyelid surgery can induce astigmatism. Therefore, it might be better to perform upper eyelid surgery before refractive procedures.

Informed Consent: Written consent was obtained from the participants.

Ethics Committee Approval: This study was approved by the Ethical Committee of the Istanbul University School of Medicine.

Peer Review: Externally peer-reviewed. 
Author Contributions: Conception/Design of Study- E.A., N.A.C.; Data Acquisition- E.A., N.A.C.; Data Analysis/Interpretation- E.A., N.A.C.; Drafting Manuscript- E.A., N.A.C.; Critical Revision of Manuscript- E.A., N.A.C.; Final Approval and Accountability- E.A., N.A.C.; Technical or Material Support- E.A., N.A.C.; Supervision- E.A., N.A.C.

Conflict of Interest: Authors declared no conflict of interest.

Financial Disclosure: Authors declared no financial support.

Etik Komite Onayı: Bu çalışma için etik komite onayı İstanbul Üniversitesi Tıp Fakültesi Etik Kurulu'ndan alınmıştır.

Bilgilendirilmiş Onam: Katılımcılardan bilgilendirilmiş onam alınmıştır.

Hakem Değerlendirmesi: Dış bağımsız.

Yazar Katkıları: Çalışma Konsepti/Tasarım- E.A., N.A.C.; Veri Toplama- E.A., N.A.C.; Veri Analizi/Yorumlama- E.A., N.A.C.; Yazı Taslağı- E.A., N.A.C.; İçeriğin Eleştirel İncelemesi- E.A., N.A.C.; Son Onay ve Sorumluluk- H E.A., N.A.C.; Malzeme ve Teknik Destek- E.A., N.A.C.; Süpervizyon- E.A., N.A.C.

Çıkar Çatışması: Yazarlar çıkar çatışması beyan etmemişlerdir.

Finansal Destek: Yazarlar finansal destek beyan etmemişlerdir.

\section{REFERENCES}

1. Merriam WW, Ellis FA, Helveston EM. Congenital blepharoptosis, anisometropia and amblyopia. Am J Ophthalmol 1980;89:401-7. [CrossRef]

2. Gullstrand A. The cornea. In: Southall JPC, editor. Helmholtz's treatise on physiological optics. New York, NY: Dover Publications Inc; 1962:320-1.

3. Mavrikakis I, Detorakis ET, Baltatzis S, Yiotakis I, Kandiloros D. Corneal topography with upper eyelid platinum chain implantation using the pretarsal fixation technique. Med Hypothesis Discov Innov Ophthalmol 2015;4(1):9-13.

4. Eğrilmez S, Dalkılıç G, Yagci A. Vector analysis software on analyzing astigmatism. Turk J Ophthalmol 2003;33:404-16.

5. Eğrilmez S, Ates H, Nalcaci S, Andac K, Yagci A. Surgically induced corneal refractive change following glaucoma surgery: nonpenetrating trabecular surgeries versus trabeculectomy. J Cataract Refract Surg 2004;30(6):1232-9. [CrossRef]

6. Fox SA. Surgery of Ptosis. Baltimore, MD: The Williams \& Wilkins Company; 1980:75-80.

7. Rosenfield LK. The pinch blepharoplasty revisited. Plast Reconstr Surg 2005;115(5):1405-12. [CrossRef]
8. Lehmann RP, Houtman DM. Visual performance in cataract patients with low levels of postoperative astigmatism: full correction versus spherical equivalent correction. Clin Ophthalmol 2012;6:333-8. [CrossRef]

9. Wilkins MR, Allan B, Rubin G. Spectacle use after routine cataract surgery $\mathrm{Br}$ J Ophthalmol 2009;9310):1307-12. [CrossRef]

10. Hayashi K, Hayashi H, Nakao F, Hayashi F. Influence of astigmatism on multifocal and monofocal intraocular lenses. Am J Ophthalmol 2000;130(4):477-82. [CrossRef]

11. Altin Ekin M, Karadeniz Ugurlu S.Prospective analysis of visual function changes in patients with dermatochalasis after upper eyelid blepharoplasty. Eur J Ophthalmol. 2019 Jun 17:1120672119857501. [CrossRef]

12. Simsek IB, Yilmaz B, Yildiz S, Artunay O. Effect of upper eyelid blepharoplasty on vision and corneal tomographic changes measured by Pentacam. Orbit 2015;34(5):263-7. [CrossRef]

13. Dogan E, Akbas Kocaoglu F, Yalniz-Akkaya Z, Elbeyli A, Burcu A, Ornek F. Scheimpflug imaging in dermatochalasis patients before and after upper eyelid blepharoplasty. Semin Ophthalmol 2015;30(3):193-6. [CrossRef]

14. Savino G, Battendieri R, Riso M, Traina S, Poscia A, D'Amico G, Caporossi A. Corneal topographic changes after eyelid ptosis surgery. Cornea 2016;35(4):501-5. [CrossRef]

15. Gingold MP, Ehlers WH, Rodgers IR, Hornblass A. Changes in refraction and keratometry after surgery for acquired ptosis. Ophthalmic Plast Reconstr Surg 1994;10:241-6. [CrossRef]

16. Kim YK, In JH, Jang SY. Changes in corneal curvature after upper eyelid surgery measured by corneal topography. J Craniofac Surg 2016;27(3):e235-8. [CrossRef]

17. Holck DE, Dutton JJ, Wehrly SR. Changes in astigmatism after ptosis surgery measured by corneal topography. Ophthalmic Plast Reconstr Surg 1998;14(3):151-8. [CrossRef]

18. Kao SC, Tsai CC, Lee SM, Liu JH. Astigmatic change following congenital ptosis surgery. Zhonghua Yi Xue Za Zhi (Taipei) 1998;61(12):689-93.

19. Klimek DL, Summers CG, Letson RD, Davitt BV. Change in refractive error after unilateral levator resection for congenital ptosis. JAAPOS 2001;5(5):297-300. [CrossRef]

20. Zinkernagel MS, Ebneter A, Ammann-Rauch D. Effect of upper eyelid surgery on corneal topography. Arch Ophthalmol 2007;125(12):1610-2. [CrossRef]

21. Brown MS, Siegel IM, Lisman RD. Prospective analysis of changes in corneal topography after upper eyelid surgery. Ophthal Plast Reconstr Surg 1999;15:378-83. [CrossRef]

22. Kim YK, In JH, Jang SY. Changes in corneal curvature after upper eyelid surgery measured by corneal topography. J Craniofac Surg 2016;27(3):e235-8. [CrossRef] 